\title{
A COMPARISON OF ONLINE AND OFFLINE GENDER AND GOAL DIRECTED SHOPPING ONLINE
}

\author{
Robert Davis*, Unitec Institute of Technology, New Zealand. \\ Bodo Lang, University of Auckland, New Zealand. \\ Josefino San Diego, Unitec Institute of Technology, New Zealand. \\ Track : Electronic and Interactive Marketing
}

\begin{abstract}
The aim of this paper is to model the effect of the consumers' perceptions of their offline and online gendered behaviour on online utilitarian shopping motivation and purchase intentions. We propose that when consumers shop online their behaviour is mediated by two gendered behaviors; offline and online. Therefore, gender is defined by the environments effect on behaviour To test this proposition, five hundred and fifteen usable responses were collected in face-to-face interviews. The conceptual model was tested with confirmatory factors analysis (CFA) and structural equation modeling (SEM) across 5 product categories. Our findings show that the effect of a consumer's perception of their gendered behaviour offline vs. online on, online utilitarian shopping motivation and purchase intentions is significantly different. We conclude that online gender for females has a strong mediating effect across all product categories on online utilitarian shopping motivation and purchase intentions. For males it is their offline gender that has a strong mediating effect. Research implications are discussed.
\end{abstract}

\section{INTRODUCTION}

The aim of this paper is to model the effect of consumers' perceptions of their offline and online gendered behaviour on,

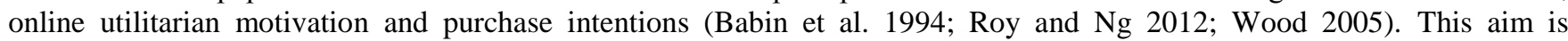
concerned with optimizing the online shopping experience (Sheehan 1999), suggesting how variations in gender on and offline enable consumers to allow consumers "to experience the body's needs by a virtual projection of the mind into cyberspace" (Achrol and Kotler 2012, p. 38). We propose that when consumers shop online their behaviour is mediated by two gendered behaviors; offline and online. This research is important as online and offline behaviour is not well understood (Brown et al. 2007; Danaher et al. 2003). While previous research has measured gender effects (e.g., Cleveland et al. 2006; Dobscha 2003; Hyllegard et al. 2005; Laforet 2008) there have been no studies to measure gender-related behaviour offline and online, modeling the impact on online shopping motivation and purchase intentions (Alreck and Settle 2002). Otnes and McGrath (2001) argue this is a gap in our understanding because gender-related shopping behaviour often contradicts socially constructed and biological stereotypes (Gentry et al. 2003). Further, Bettany et al. (2010, p. 16) argues that we should be moving towards developing theories that help us understand gender related issues. McLaren et al. (2004) supports this position requesting: "comparative research is also required to look at multiple consumption" of "the same product or service and assess how the gendered and gendering effects differ across the respective social settings." The existing literature on whether gender matters in the relationship between utilitarian motivation and purchase intentions is disparate. Several studies have portrayed women online to be the principal shoppers (Dholakia and Chiang 2003; Mitchell and Walsh 2004), but others suggests that males tend to shop online more in technology-mediated channels (Wajcman 1991). Recent work has suggested there is no difference between males and females in their shopping behaviour (Kim and Forsythe 2008).

Little help has come from other research to help to resolve this debate. For example, women are portrayed as nurturing, person-oriented, and child-centered, whereas men were seen to be competitive and work-oriented (Alreck and Settle 2002; Dholakia and Chiang 2003). Rodgers and Harris (2003) found that in nearly every study exploring gender in online shopping environments, males were typically reported to be the dominant online shopper. Gendered behaviour within technology environments is further illustrated in Smith and Whitlark's (2001) study of the online consumer behaviour of males and females. Situations in which women tended to be associated with when using technology-mediated services included making friends, fighting for causes, nurturing children, role-playing, and improving on-the-job productivity (Neilson 2010). Men were information hungry and desired detailed and accurate information to questions relating to investments, product purchases, and personal interests. The limitation of these studies is that they fail to challenge current stereotypes (Anderson 1986; Marsh 1985). Some resolution to the debate comes from Bem (1974) who proposed that gender is behaviour, popularizing the concept of psychological androgyny, that is, gender is a function of behaviour (Smiler and Epstein 2010, p. 
134). Smiler and Epstein (2010) have cautioned against its use because of it psychometric properties and argued that this approach to measuring gender is over 30 years old and out of date compared to today's social environment. To help reconcile this debate we model the effect of the consumers' perceptions of their offline and online gendered behaviour on utilitarian motivation and purchase intentions. We suggest that the variation may be constructed by the context in which the consumer exists, that is, gender offline or online. Therefore, our research question is: Does gender (online and offline) matter in the relationship between utilitarian motivation online and purchase intentions online?

The contribution of this research is three-fold. We conceptualize and measure gender in different environments and model the impact of these differences on shopping motivation and purchase intention. This is important because there is no empirical evidence that supports the hypothesis that a consumer's gender is the same offline and online. The measurement of gender in this way has also not been done before and its effects on shopping motivation are unclear. Furthermore, marketers may be incorrectly assuming that, in the design of their strategies, no account should be taken of gender differences. This study will also help marketers to understand the different ways in which males and females may exhibit cross-gender perceptions of techno-consumption. This could provide further insight into some of the key situations that drive men and women to use technology-mediated channels. This paper is structured as follows. To build our conceptual model and hypotheses, we first discuss the importance of shopping motivation in terms of utilitarian consumption and gendered behaviour. This leads to our conceptual model and hypotheses. The methodology precedes our data analysis and discussion of the results and their implications.

\section{CONCEPTUAL MODEL AND HYPOTHESES}

In this research we first posit that, in the relationship between a consumer's utilitarian motivation to shop online and retail purchase intentions, gender will have a mediating effect. Gender behaviour will differ because of the environment in which the consumer shops, that is, whether online or offline (Brown et al. 2007; Noble et al. 2006). This proposition is supported by Sengupta et al. (2002) and Argo et al. (2006) and, who found empirical evidence that a consumer's gender related behaviour will vary because of the effect of symbolic consumption and social comparison. Offline a male engages in what society perceives to be typical male behaviors. These male traits diminish online: he is able to break free of (1) the gender constraints and comparisons rooted in society (Berger and Luckmann 1967; Mitchell and Walsh 2004; Thompson 1996) and (2) restraints defined by biological determinism (Dobscha 2003; Gentry et al. 2003; Martin 2003). He is able to change his behaviour online because there is no physical interaction (Davis et al. 2000). He is able to participate in female-oriented chatrooms, browse for and purchase female-oriented products such as skincare supplies, and even develop an online relationship with another male. Once the online experience is over, he then reverts back to his male self. Second: the importance of utilitarian shopping motivations (Holbrook 1982, Holbrook and Hirschman 1982; Holbrook and Gardner 1998) offline and online (Childers et al. 2001; Wood 2005). Motivations for retail shopping can differ, depending on whether the consumer's motivation is primarily experiential (hedonic) or goal-directed (utilitarian) (Wang 2007).

A utilitarian approach at its extreme is associated with terms such as task-oriented, instrumental, rational, and efficient and is also defined by Ahtola (2001) as an attitude pertaining to the usefulness, value, and wiseness of a particular behaviour as exhibited by a consumer. Utilitarian motives usually reflect a work mentality (Babin et al. 1994) and are dependent on whether the task at hand was accomplished. The consumer employing a utilitarian approach will thus experience greater levels of satisfaction once they feel they have made an efficient and purposeful purchase especially if done in a fastidious manner. Dholakia (1999) observes that the motivations and approaches taken towards shopping are reflected by the cultural and socialization conditions surrounding the consumer. Since gender is also culturally derived (Palan 2001), it is assumed that the cultural understandings of what is masculine and what is feminine will be associated with the approach taken towards shopping. Since shopping is categorized mainly as a female-oriented activity (Dholakia 1999) and is reported by women to help them relax, socialize and to enhance a special occasion (Buttle and Coates, 1984), the literature promotes that femaleoriented consumers will be associated with hedonic rather than utilitarian shopping behaviour (Dittmar et al. 2004).

A consumer employing hedonic feminine behaviour may tend to savor the shopping experience by participating in the online chat rooms and reading book reviews. Men want detailed and accurate information about the products they wish to purchase, yet they are not willing to work very hard to get it (Smith and Whitlark 2001). Thus, the literature argues that masculineoriented customers will be associated with utilitarian shopping behaviour (Dittmar et al. 2004), wanting to complete the task of shopping with minimum time and effort. A key proposition of this research is that consumers may display different gender orientations online compared to their offline social and biological construction, challenging what Cockburn and Ormrod (1993) showed technology related gender symbolism. The Internet in contrast has allowed consumers greater freedom of expression in their gender (Chen et al. 2002). McLaren et al. (2004, p. 149) argues that the Internet provides an "escape 
route" from the "cultural constrictions of gender." Kozinets et al. (2003) and Schau and Muniz (2003) argue for prosthetic feminism online promoting gender online as the private androgynous self (Argo et al. 2006) that is more akin to their own gendered symbolic consumption (Sengupta et al. 2002). Therefore, given these two key research propositions, we model the mediating effect of the consumers perceived gender behaviour (offline and online) on utilitarian shopping motivation online and purchase intentions online (Figure 1). In our model we have three distinct pathways: (1) the Mediated Gender Pathways where the relationship between motivation and purchase intention is mediated by offline or online gender (Path a and Path b) and, (2) Control Pathways which shows the relationship between motivation and offline or online gender (Path a) and, offline or online gender and purchase intentions (Path b) and, (3) the relationship between motivation and purchase intention is not mediated by offline or online gender (Path c). Our hypotheses are in Table 2 with a summary of the key results.

\section{METHODOLOGY}

Five-hundred and fifty consumers responded face-to-face to a questionnaire. All consumers who walked past the interviewers were considered to be potential respondents. The interviewers were rotated around four locations in Auckland (New Zealand); east, west, south, and north. Every potential respondent was asked to participate so they had an equal chance to complete the survey. Those that agreed to participate were asked to respond to a structured questionnaire. Respondents were screened with the following question: Have you bought anything online in the last 6 months? The survey yielded 515 usable responses. Around two thirds (63\%) of respondents had shopped between 1 to 5 years online and females (61\%) and males $(65 \%)$ did not differ much in this regard. The characteristics of the sample are broadly consistent with the national population statistics (www.stats.govt.nz). Fifty-two per cent of the respondents were male and $48 \%$ were female. The majority of the respondents (58\%) were 25 years and under. About $48 \%$ of the respondents have received a college degree and $57 \%$ were single. Thirty-seven per cent are NZ European and $42 \%$ of the respondents are fully employed. Thirty-five per cent of the respondents have an annual income of within the $\$ 30,001-\$ 50,000$ range. The questionnaire was designed with the data collection method in mind. That is, it was purposefully designed to be suitable for street intercept, face-to-face interviews. Throughout the whole questionnaire, a seven point scale was used to measure the constructs of interest $(1=$ "Strongly Disagree", 7 = "Strongly Agree"). In this study we measure gender in 2 ways: (1) The consumers' perceptions of their gender while shopping (1) online on a 7 point scale and (2) offline on a 7 point scale (Avery 2012; Bettany et al. 2010; Smiler and Epstein 2010; McLaren et al. 2004; Beere 1990) and (2) sex in our measure of gender: if they are biologically male or female (Smiler and Epstein 2010). In this study we use this to test our hypotheses across: (1) 5 product groups and (2) 3 groups of sex (overall male/female, male and female). We used the Babin et al. (1994) scale to measure utilitarian shopping motivation online (Reynolds et al. 2012). The original product groups included in the survey were similar to those used by Nielsen (http://nz.nielsen.com).

\section{RESULTS}

The analysis had three stages. The first stage was to conduct an exploratory factor analysis (PCA) to distil the product items into groups. Second and third, the analyses tested the proposed conceptual model with confirmatory factor analysis (CFA) and structural equation modeling (SEM). The process was to conduct separate measurement models for each latent variable and then to create the structural model. The approach was employed as we wanted to use an analysis method that not only supported model refinement but also had the ability to rigorously assess model fit across our ten models (Kline 1998). Before data analysis was started, initial data screening was carried out for missing values and outliers, and the normality of the dataset was tested. In our analysis, we utilized a combination of Microsoft Excel 2007 software, PASW Statistics 19 and Analysis of Moment Structures (AMOS 19) (Arbuckle 2010) for structural equation modeling (SEM). The reporting of our results is consistent with other authors (e.g., Bagozzi and Yi 2012; Jepsen 2007). The appendix shows the full results of the study.

\section{Exploratory Factor Analysis}

The questionnaire included 27 product items. In order to group the product items an exploratory factor analysis was used (e.g., Brakus et al. 2009). The Kaiser Meyer Olkin (KMO) value was 0.90 and is well over the required minimum (Hutcheson \& Sofroniou, 1999, p. 224-225). The individual item KMO values for all variables are in the range of 0.80 to 0.90 . Bartlett's test is also highly significant $(\mathrm{p}<0.001)$. Therefore, a factor analysis is appropriate. We conducted a factor analysis using a Varimax rotation. Five factors were derived and we included items that had a loading of greater than 0.34. The Cronbach's Alpha measure of internal consistency and reliability of the factors were satisfactory (Nunnally, 1978). Factors 1, 4 and 5 were highly significant based on a scree plot (variance explained $=43 \%$ ) with all 5 factors accounting for $50 \%$ of the variance explained. The 5 product categories derived from the factor analysis procedure were: (1) Group 1: Consumer 
Electronics, Computer Hardware/Software, Electronic Games/Consoles, (2) Group 2: Entertainment (Movies DVDs/videos, Recorded music, Entertainment) and Clothing/shoes, (4) Group 3: Travel Related Services, Airline Tickets, Books/Magazines, (3) Group 4: Cars, Collectibles, Insurance, Sports Equipment, Stocks/Shares, Toys, Vehicle Accessories and, (5) Group 5: Art, Flowers, Food, Furniture, Garden, Health and Beauty, Home Appliances, Jewellery, Ornaments. We found these product groups to be generally consistent with previous research on gender and product choice (McDonagh and Weightman 2002; Dholakia and Chiang 2003).

\section{Confirmatory Factor Analysis (CFA)}

The convergent and discriminant validity of the constructs were tested using the confirmatory factor analysis (CFA) that combined all constructs concurrently. Maximum likelihood estimation (MLE) was used to fit the models (Pampel 2000). Construct refinement was enabled by an analysis of covariance residuals and modification indices, and exclusion of items until the goodness-of-fit was achieved, while maintaining theoretical meaningfulness. Following Bagozzi and Yi (2012) and Baumgartner and Homburg (1996) the following measures were used to assess the model fit: Goodness-of-Fit Indices, chisquared $\left(X^{2}\right)$, the comparative fit index (CFI) and normalized fit index (NFI). For CFI and NFI, values close to 1 are indicative of good model fit (Bentler 1990). The root mean square errors of approximation (RMSEA) was calculated for the overall model and according to Bentler (1990), values below 0.05 indicate close fit and values up to 0.08 are reasonable. Finally, the standardized root mean squared residual (SRMR) as described by Hu and Bentler (1995) computes how much the model explains the correlations to within an average error. The final measurement models show a reasonably good fit and most of the fit indices are above or close to the required minimum threshold level. The ratio of minimum discrepancy to degree of freedom (chi-square/d.f. ratio) should be less than 5 or preferably less than 2 (Bentler 1990). The GFI index is above the threshold of 0.90 and CFI is close to 1 (Bentler, 1990) for every construct. Composite reliability is an indicator of the shared variance among the set of observed variables used as indicators of a latent construct (Bacon et al 1995). The two items included in utilitarian motivation were: (1) respondents accomplished what they wanted to do on this online shopping trip; and (2) while shopping online, respondents found just the item(s) they were looking for. The two items included in UT were: (1) respondents accomplished just what they wanted to on this shopping trip; and (2) while shopping online, respondents found just the item(s) they were looking for. The construct reliability for these UT items was computed to be 0.75 , above the recommended value of 0.70 or higher. In addition, the coefficient alpha value was 0.75 , above the threshold value of 0.70 that Nunnally (1978) recommends. Moreover, the average variance extracted (AVE) value was 0.60 , which is above the recommended threshold of 0.5 (Chin 1998; Fornell and Lacker 1981).

\section{Structural Equation Modeling}

Our results showed adequate model fit across or measures (GFI, CFI, TLI, RMSEA, SRMR, $\mathrm{X}^{2} / \mathrm{DF}$ ) for all our model variations across the 5 product groups when modeling the relationship between utilitarian shopping motivation online and online purchase intentions, as well as the mediating effect of gender (offline and online) (Bagozzi and Yi 2012; Baumgartner and Homburg 1996). Table 1 gives details of the model fit results. Overall, when manipulating product group and gender our results compare 30 competing models.

\section{Results Summary}

Table 2 summaries the results across our hypotheses and models. We conclude the following:

1. Utilitarian shopping motivation online has a significant effect on gender (online) overall. Strongly for females but not for males.

2. Gender (online) has a significant effect on purchase intentions online.

3. Utilitarian shopping motivation online has a significant effect on purchase intentions online mediated by gender (online) overall and strongly for females but not for males.

4. Utilitarian shopping motivation online has a significant effect on purchase intentions online overall and for males but not for females (online and offline gender model).

5. Utilitarian shopping motivation online has a significant effect on gender (offline) for males but not overall and for females.

6. Gender (offline) has a significant effect on purchase intentions online overall (weak) but strongly for males and females.

7. Utilitarian shopping motivation online has a significant effect on purchase intentions online mediated by gender (offline) for males but not overall and for females. 


\section{DISCUSSION}

In this study we measured whether gender matters in the relationship between utilitarian motivation and purchase intentions online. Our findings show that the effect of a consumer's perception of their gendered behaviour offline vs. online on, online utilitarian shopping motivation and purchase intentions is significantly different. We conclude that online gender for females has a strong mediating effect across all product categories on, online utilitarian shopping motivation and purchase intentions. For males it is their offline gender that has a strong mediating effect. Therefore, female gendered behavior online is oriented by the notion of rational thought and process of structured decision making based upon known outcomes and set constraints. Because the online and offline gender effect varies in its effects we argue that this challenges the definition of gender in shopping in terms of social construction and biological determinism (Caterall and MacLaran 2002). This is supported by Kozinets et al. (2003, p. 92) argument online for "maneuvering... of gender positions." Schau and Muniz (2003, p. 93) point out gender online is a performance. This may be because gender offline for females is strongly oriented hedonic value. When females choose to purchase online they become more rational and goal directed in their behavior. The differences in gender position could also be attributed to the fact that the online environment is a hidden platform for experiences, allowing gender variation to play a more important role in that experience. In sum, online environments enhance particular motivations and associated gender behaviors (Bardhi and Arnould, 2005). With the added discretionary nature consumers are able to maintain their anonymity, exhibiting their desired behaviors without any form of social constraints or criticisms.

Given this proposition, Argo et al. (2006) argues that suggest that consumers may change, misrepresent or 'lie' about their gender online (private self) compared to offline (public self) because of self-threatening social comparison. Social comparison in terms of gender threatens the public and privates selves and is the consumers' way to challenge social constructivism and biological determinism online. Misrepresenting purchase behavior helps to create a positive self-image in social interactions and experience different or more consistent gender orientations. In this way individuals tend to encode information in terms of gender (Bem, 1974). Achrol and Kotler (2012, p. 39) provide a summary argument: "the digital world will offer nearly endless possibilities of shaping life and experiences so that the physical world will pale in significance and may well become a secondary world in which our bodies live wired to a digital reality... We stand at the threshold of a virtual world of experiences and an incredible expansion of the science by which experiences are experienced." We also suggest that difference between gender orientation on vs. offline could be attributed to homophily (Brown et al. 2007, p. 9) who argue that: "homophily of an interpersonal relationship, as based on an evaluation of individual characteristics, is not particularly relevant in an online context.... it is notions of shared group interests and group mind-set, evaluated at the level of the Web site itself, which drive online homophily." Therefore, it could be suggested that for females and males, interpersonal relationships tend to be grounded offline. In contrast when females want to transact online they become more strongly

oriented around the online service offering; rationally evaluating the online brand with their known objectives and set constraints.

\section{MANAGERIAL IMPLICATIONS}

The major practical implication of this study is to acknowledge that consumers with strongly female orientation online will place a greater importance and emphasis on consumption that fulfills task-oriented outcomes which meet a desired end-state. Traditionally online marketers would have associated this type of behavior offline and online with consumers who are strongly male. Possibly, consumers online who are more female online use the offline shopping environment to explore and socially interact in the consumption experience. To transact they may shift online to obtain the best value or lowest price. Marketers need to find ways to channel these consumers offline, online (Davis and Sajtos 2008). For example, using advertising through the television channel to stimulate the consumers use of their smartphone for shopping online with the right deal to complete the transaction. Marketers may also necessitate the need to revise traditional definitions of gender. It has implications for measuring a consumer's gender within technology environments as opposed to the consumer's gender being stated in a customer profile. Such an approach may provide a more meaningful assessment for digital marketers.

\section{RESEARCH IMPLICATIONS}

The main limitations of our study relate to a lack qualitative work to help explain our results. We suggest using a grounded theory approach to further explore gender's role in shopping motivation and purchase decisions online. Further, work should also clarify differences in online and offline behaviour through a link to actual purchase behaviour. Also, utilitarian consumption online is only one aspect of a consumer's motivation to shop online. For example, the individual as well as the 
combined effects of: cognitive style, trust and techno-consumption (Van Slyke et al. 2002). Second, the misrepresentation of gender online and offline raised the issue of authenticity. This is a particular issue when transactions are enacted online. Rose and Wood (2005, p. 284) argues "the connectedness of objects to highly valued elements of consumers' lived experience grounds judgments of authenticity in the "real" world." This raises the question that when gender is manipulated online and offline what environment most influences the consumer's judgments of a true lived experience and thus their evaluation of the authentic. Consumers may desire to disrupt the authentic and symbolically redefine their gender. A performance of the 'cannibalization' of self: to escape from a self-threatening social comparison (Argo et al. 2006). This research is about online shopping but what about ubiquitous markets and the iPad and iPhone? We also suggest that to increase our emphasis on gender in consumer behaviour research that we look beyond generic products and perceptions of gendered behaviour: (1) feminism (Wilkes and Laverie 2007); (2) leisure (golf; McGinnis et al. 2012); (3) masculinity (Harrison and Gentry 2010); and (4) conspicuous consumption.

FIGURE 1. CONCEPTUAL MODEL

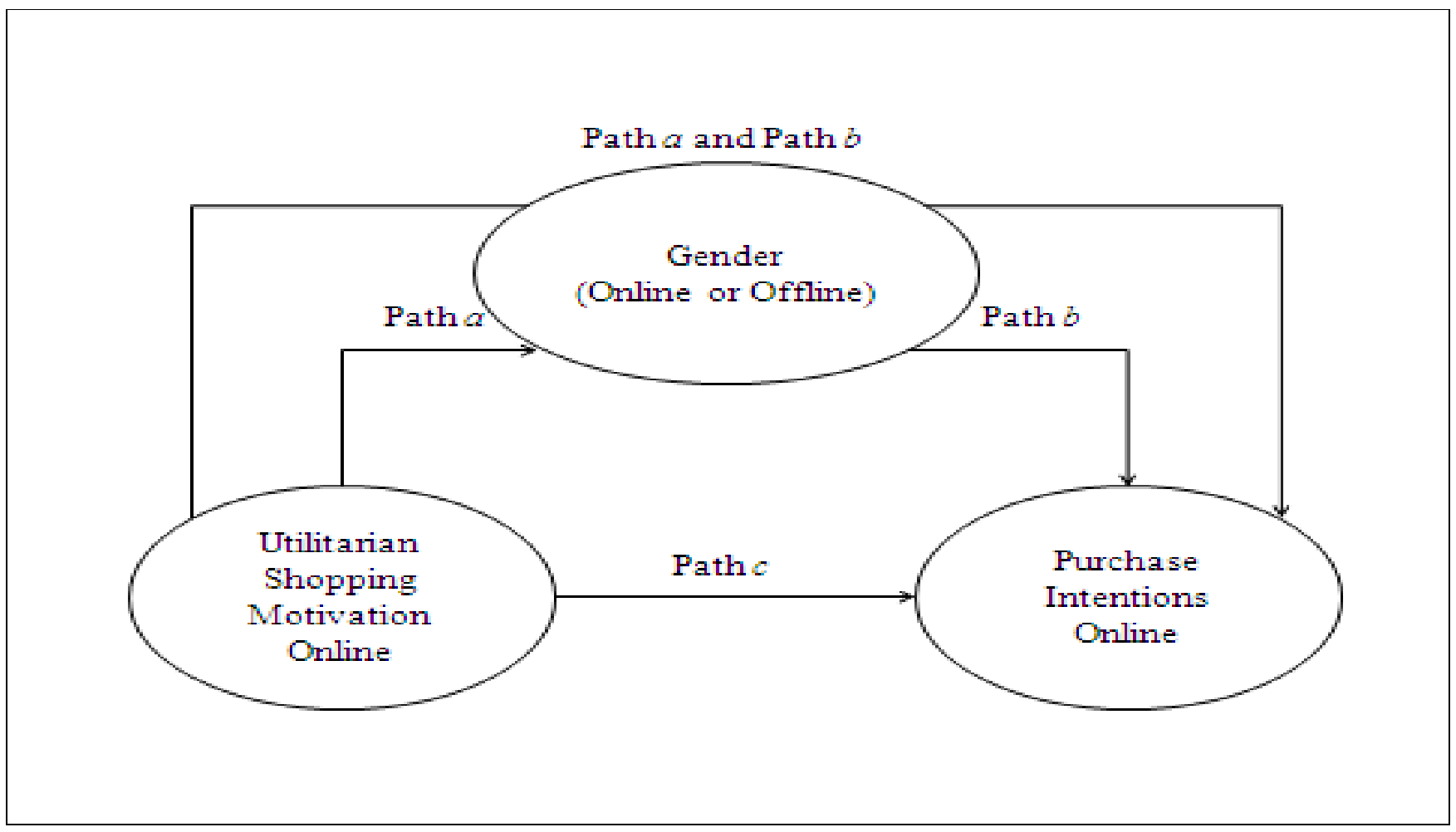


TABLE 1. MODEL FIT

$(\mathrm{ON}=$ ONLINE, OFF $=$ OFFLINE $)$

\begin{tabular}{|c|c|c|c|c|c|c|c|c|c|c|c|c|c|c|c|c|c|c|c|c|c|c|c|}
\hline & & & \multicolumn{7}{|c|}{ n=515 (Male and Female) } & \multicolumn{7}{|c|}{$\mathrm{n}=268$ (Male only) } & \multicolumn{7}{|c|}{$\mathrm{n}=247$ (Female only) } \\
\hline & $\frac{\bar{g}}{g}$ & ڤ్ & $\sqrt{2}$ & 先 & 它 & $\exists$ & 焉 & 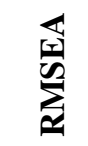 & 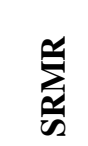 & $\sqrt{2}$ & 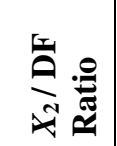 & 完 & $\vec{G}$ & 崈 & 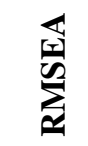 & $\sum_{\frac{\pi}{\sigma}}^{\mathscr{a}}$ & $\sqrt{7}$ & 瓷 & 它 & $\vec{F}$ & $\overrightarrow{\mathrm{J}}$ & 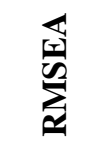 & $\sum_{\frac{\pi}{n}}^{n}$ \\
\hline 1 & $\begin{array}{l}\text { Utilitarian } \\
\text { /Gender } \\
\text { (ON) }\end{array}$ & \multirow{2}{*}{1} & 36.42 & 3.04 & 0.97 & 0.95 & 0.98 & 0.06 & 0.03 & 29.74 & 2.48 & 0.96 & 0.92 & 0.97 & 0.07 & 0.03 & 20.67 & 1.72 & 0.98 & 0.96 & 0.98 & 0.05 & 0.04 \\
\hline 2 & $\begin{array}{l}\text { Utilitarian } \\
\text { /Gender } \\
\text { (OFF) }\end{array}$ & & 41.34 & 3.45 & 0.97 & 0.94 & 0.98 & 0.07 & 0.03 & 34.96 & 2.91 & 0.95 & 0.92 & 0.97 & 0.09 & 0.04 & 22.99 & 1.92 & 0.97 & 0.95 & 0.97 & 0.06 & 0.04 \\
\hline 3 & $\begin{array}{l}\text { Utilitarian } \\
\text { /Gender } \\
\text { (ON) }\end{array}$ & \multirow{2}{*}{2} & 25.98 & 2.17 & 0.98 & 0.96 & 0.99 & 0.05 & 0.03 & 31.66 & 2.64 & 0.93 & 0.90 & 0.97 & 0.08 & 0.04 & 13.63 & 1.05 & 0.99 & 0.99 & 0.99 & 0.01 & 0.04 \\
\hline 4 & $\begin{array}{l}\text { Utilitarian } \\
\text { /Gender } \\
\text { (OFF) }\end{array}$ & & 22.45 & 1.87 & 0.98 & 0.97 & 0.99 & 0.04 & 0.03 & 34.63 & 2.89 & 0.93 & 0.90 & 0.97 & 0.08 & 0.04 & 11.26 & 0.94 & 0.99 & 0.99 & 0.99 & 0.01 & 0.03 \\
\hline 5 & $\begin{array}{l}\text { Utilitarian } \\
\text { /Gender } \\
\text { (ON) }\end{array}$ & \multirow{2}{*}{3} & 10.71 & 1.53 & 0.99 & 0.97 & 0.99 & 0.03 & 0.03 & 10.14 & 1.45 & 0.98 & 0.96 & 0.99 & 0.04 & 0.04 & 11.75 & 1.68 & 0.97 & 0.94 & 0.99 & 0.05 & 0.04 \\
\hline 6 & $\begin{array}{l}\text { Utilitarian } \\
\text { /Gender } \\
\text { (OFF) }\end{array}$ & & 7.61 & 1.09 & 0.99 & 0.99 & 0.99 & 0.01 & 0.02 & 14.43 & 2.06 & 0.96 & 0.91 & 0.98 & 0.06 & 0.04 & 10.15 & 1.45 & 0.98 & 0.96 & 0.99 & 0.04 & 0.05 \\
\hline 7 & $\begin{array}{l}\text { Utilitarian } \\
\text { /Gender } \\
\text { (ON) }\end{array}$ & \multirow{2}{*}{4} & 73.75 & 2.17 & 0.97 & 0.96 & 0.97 & 0.05 & 0.04 & 78.60 & 2.31 & 0.93 & 0.91 & 0.95 & 0.07 & 0.05 & 48.75 & 1.48 & 0.98 & 0.97 & 0.96 & 0.04 & 0.04 \\
\hline 8 & $\begin{array}{l}\text { Utilitarian } \\
\text { /Gender } \\
\text { (OFF) }\end{array}$ & & 72.07 & 2.12 & 0.97 & 0.96 & 0.97 & 0.05 & 0.04 & 67.00 & 1.97 & 0.95 & 0.93 & 0.95 & 0.06 & 0.05 & 50.51 & 1.49 & 0.97 & 0.97 & 0.96 & 0.04 & 0.04 \\
\hline 9 & $\begin{array}{l}\text { Utilitarian } \\
\text { /Gender } \\
\text { (ON) }\end{array}$ & \multirow[b]{2}{*}{5} & 146.82 & 2.77 & 0.93 & 0.91 & 0.95 & 0.06 & 0.05 & 123.12 & 2.32 & 0.92 & 0.90 & 0.93 & 0.07 & 0.06 & 106.16 & 2.00 & 0.91 & 0.90 & 0.94 & 0.06 & 0.05 \\
\hline 10 & $\begin{array}{l}\text { Utilitarian } \\
\text { /Gender } \\
\text { (OFF) }\end{array}$ & & 153.52 & 2.90 & 0.93 & 0.91 & 0.95 & 0.06 & 0.05 & 130.29 & 2.46 & 0.91 & 0.90 & 0.92 & 0.07 & 0.06 & 112.03 & 2.11 & 0.90 & 0.90 & 0.93 & 0.07 & 0.06 \\
\hline
\end{tabular}


TABLE 2. HYPOTHESIS CONCLUSIONS: MALE/FEMALE, MALE AND FEMALE $(\mathrm{A}=\mathrm{ACCEPT}, \mathrm{R}=\mathrm{REJECT})$

\begin{tabular}{|c|c|c|c|c|c|c|c|c|c|c|}
\hline \multirow{2}{*}{\multicolumn{2}{|c|}{ Hypothesis }} & \multicolumn{3}{|c|}{ n=515 (Male/Female) } & \multicolumn{3}{|c|}{$\mathrm{n}=268$ (Male) } & \multicolumn{3}{|c|}{$\mathrm{n}=247$ (Female) } \\
\hline & & \multirow{2}{*}{$\begin{array}{l}\mathbf{A} \\
3\end{array}$} & \multirow{2}{*}{$\begin{array}{l}\mathbf{R} \\
2\end{array}$} & \multirow[b]{2}{*}{ A } & \multirow{2}{*}{$\begin{array}{l}\mathrm{A} \\
0\end{array}$} & \multirow{2}{*}{$\begin{array}{c}\mathbf{R} \\
5\end{array}$} & \multirow[b]{2}{*}{$\mathrm{R}$} & \multirow{2}{*}{ A } & \multirow{2}{*}{$\begin{array}{l}\mathbf{R} \\
0\end{array}$} & \multirow[b]{2}{*}{ A } \\
\hline $\mathrm{H}_{1}$ & $\begin{array}{l}\text { Utilitarian shopping motivation online has a } \\
\text { significant effect on gender (online). }\end{array}$ & & & & & & & & & \\
\hline & Product Group & $1,2,5$ & 3,4 & & & ALL & & $1,2,3,4,5$ & & \\
\hline \multirow[t]{2}{*}{$\mathrm{H}_{2}$} & $\begin{array}{l}\text { Gender (online) has a significant effect on } \\
\text { purchase intentions online. }\end{array}$ & 2 & 3 & A & 3 & 2 & A & 4 & 1 & A \\
\hline & Product Group & 1,5 & $2,3,4$ & & $\begin{array}{c}3,4, \\
5\end{array}$ & 1,2 & & $1,3,4,5$ & 2 & \\
\hline \multirow[t]{2}{*}{$\mathrm{H}_{3}$} & $\begin{array}{l}\text { Utilitarian shopping motivation online has a } \\
\text { significant effect on purchase intentions } \\
\text { online mediated by gender (online). }\end{array}$ & 2 & 3 & A & 0 & 5 & $\mathrm{R}$ & 4 & 1 & A \\
\hline & Product Group & 1,5 & $2,3,4$ & & & ALL & & $1,3,4,5$ & 2 & \\
\hline \multirow[t]{2}{*}{$\mathrm{H}_{4}$} & $\begin{array}{l}\text { Utilitarian shopping motivation online has a } \\
\text { significant effect on purchase intentions } \\
\text { online. }\end{array}$ & 3 & 2 & A & 2 & 3 & A & 0 & 5 & $\mathrm{R}$ \\
\hline & Product Group & $1,2,3$ & 4,5 & & 1,2 & $\begin{array}{c}3,4, \\
5\end{array}$ & & & ALL & \\
\hline \multirow[t]{2}{*}{$\mathrm{H}_{5}$} & $\begin{array}{l}\text { Utilitarian shopping motivation online has a } \\
\text { significant effect on gender (offline). }\end{array}$ & 0 & 5 & $\mathrm{R}$ & 3 & 2 & A & 0 & 5 & $\mathrm{R}$ \\
\hline & Product Group & & ALL & & $\begin{array}{c}1,4, \\
5\end{array}$ & 2,3 & & & ALL & \\
\hline \multirow[t]{2}{*}{$\mathrm{H}_{6}$} & $\begin{array}{l}\text { Gender (offline) has a significant effect on } \\
\text { purchase intentions online. }\end{array}$ & 1 & 4 & A & 5 & 0 & A & 5 & 0 & A \\
\hline & Product Group & 1 & $\begin{array}{c}2,3,4 \\
5\end{array}$ & & $\begin{array}{c}1,2 \\
3,4, \\
5\end{array}$ & & & $1,2,3,4,5$ & & \\
\hline \multirow[t]{2}{*}{$\mathrm{H}_{7}$} & $\begin{array}{l}\text { Utilitarian shopping motivation online has a } \\
\text { significant effect on purchase intentions } \\
\text { online mediated by gender (offline). }\end{array}$ & 0 & 5 & $\mathrm{R}$ & 4 & 1 & A & 0 & 5 & $\mathrm{R}$ \\
\hline & Product Group & & ALL & & $\begin{array}{l}1,2, \\
4,5\end{array}$ & 3 & & & ALL & \\
\hline \multirow[t]{2}{*}{$\mathrm{H}_{8}$} & $\begin{array}{l}\text { Utilitarian shopping motivation online has a } \\
\text { significant effect on purchase intentions } \\
\text { online. }\end{array}$ & 3 & 2 & A & 2 & 3 & A & 1 & 4 & A \\
\hline & Product Group & $1,2,3$ & 4,5 & & 1,2 & $\begin{array}{l}3,4, \\
5\end{array}$ & & 2 & $\begin{array}{l}1,3, \\
4,5\end{array}$ & \\
\hline
\end{tabular}

\section{REFERENCES}

Achrol, R., \& Kotler, P. (2012). Frontiers of the marketing paradigm in the third millennium. Journal of the Academy of Marketing Science, 40 (1), 35-52.

Arbuckle, J. L. (2010). Amos 19 User's Guide. Chicago, IL.

Alreck, P., \& Settle, R. B. (2002). Gender effects on internet, catalogue and store shopping. Journal of Database Marketing, $9(2), 150-162$.

Anderson, K. L. (1986). Androgyny, flexibility, and individualism. Journal of Personality Assessment, 50 (2), 265-278.

Argo, J. J., White, K., \& Dahl, D. W. 2006. Social comparison theory and deception in the interpersonal exchange of consumption information. Journal of Consumer Research, 33 (1), 99-108.

Avery, J. J. (2012). Defending the markers of masculinity: Consumer resistance to brand gender-bending. International Journal of Research in Marketing, forthcoming. Retrieved April 23, 2012 from http://ssrn.com/abstract=1088802.

Babin, B. J., Darden, W. R., \& Griffin, M. (1994). Work and/or fun: Measuring hedonic and utilitarian shopping value. Journal of Consumer Research, 20 (4), 644-656. 
Bacon, D. R., (1995). Composite Reliability in Structural Equations Modeling. Educational and Psychological Measurement, 55 (3), 394-406.

Bagozzi, R. P., \& Youjae, Yi. (2012). Specification, evaluation, and interpretation of structural equation models. Journal of the Academy of Marketing Science, 40 (1), 8-34.

Bardhi, F., \& Arnould, E. J. (2005). Thrift shopping: Combining utilitarian thrift and hedonic treat benefits. Journal of Consumer Behaviour, 4 (4), 223-233.

Baumgartner H., \& Homburg C. 1996. Applications of structural equation modeling in marketing and consumer research: A Review. International Journal of Research in Marketing, 13 (2), 139-161.

Beere, C. A. (1990). Sex and gender issues: A handbook of tests and measures. New York: Greenwood Press.

Bem, S. L. (1974). The Measurement of Psychological Androgyny. Journal of Consulting and Clinical Psychology, 42, 155162.

Bentler, P. M., (1990). Comparative fit indexes in structural models. Psychological Bulletin, 107, 238-246.

Berger, P., \& Luckmann, T. (1967). The social construction of reality: A treatise on the sociology of knowledge. London: Penguin.

Bettany, S., Dobscha, S., Prothero, A., \& O’Malley, L. (2010). Moving beyond binary opposition: Exploring the tapestry of gender in consumer research and marketing. Marketing Theory, 10 (1), 3-28.

Brakus, J. J., Schmitt, B. H., \& Zarantonello, L. (2009). Brand experience: What is it? How is it measured? Does it affect loyalty? Journal of Marketing, 73 (3), 52-68.

Brown, J., Broderick, A. J., \& Lee, N. (2007). Word of mouth communication within online communities: Conceptualizing the online social network. Journal of Interactive Marketing, 21 (3), 2-20.

Browne, M. W., \& Cudeck, R. (1993). Alternative Ways of assessing Model Fit. In Bollen, K. A., \& Long, J. S. (Eds.), Testing Structural Equation Models. Sage, Newbury Park, CA, pp. 136-162.

Buttle, F., \& Coates, M. (1984). Shopping Motives. Service Industries Journal, 4 (1), 71-81.

Caterall, M., \& Maclaran, P. (2002) Gender perspectives in consumer behaviour: An overview and future directions. The Marketing Review, 2 (4), 405-425.

Chen, L. C. P., Davies, A., \& Elliott, R. (2002). Limits to ludic gaps: Gender and identity in a different cultural context. In P. Maclaran and E. Tissier-Desbordes (Eds.). 6th Conference on Gender, Marketing, and Consumer Behavior, June. Dublin: Association For Consumer Research.

Childers, T.L., Carr, C. L., Peck, J., \& Carson, S. (2001). Hedonic and utilitarian motivations for online retail shopping behaviour. Journal of Retailing, 77 (4), 511-535.

Chin, W. W. (1998). The partial least squares approach for structural equation modeling. In: Macoulides, G. A. (Ed.), Modern Methods for Business Research. (pp. 295-336). Mahwah, NJ: Lawrence Erlbaum Associates.

Cleveland, M., Babin, B J., Laroche, M., Ward, P., \& Bergeron, J. (2006). Information search patterns for gift purchases: A cross-national examination of gender differences. Journal of Consumer Behaviour, 3 (1), 1479-1838.

Danaher, P. J., Wilson, I. W., \& Davis, R.A. (2003). A comparison of online and offline consumer brand loyalty. Marketing Science, 22 (4), 461-476.

Davis, R., Buchanan-Oliver, M, \& Brodie R. J. (2000). Retail service branding in electronic-commerce environments. Journal of Service Research, 3 (2), 178-186.

Davis, R. A., \& Sajtos, L. (2008). Measuring consumer interactivity in response to campaigns coupling mobile and television media. Journal of advertising Research, 48 (3), 375-391.

Dholakia, R. R. (1999). Going shopping: Key determinants of shopping behaviors and motivations. International Journal of Retail and Distribution. 27, 4, 154-163.

Dholakia, R. R., \& Chiang, K. (2003) Factors driving consumer intention to shop online: An empirical investigation. Journal of Consumer Psychology, 13, (1-2), 177-183.

Dittmar, H., Long, K., \& Meek, R. (2004). Buying on the internet: Gender differences in on-line and conventional buying motivations. Sex Roles, 50, (5-6), 423-444.

Dobscha, S (2003). Introducing gender into the analysis of techno-consumption. Advances in Consumer Research. 30 , 91-93. Fornell, C., \& Larcker, D.F. (1981). Evaluating structural Equation models with unobservable variables and measurement error. Journal of Marketing Research 18, 39-50.

Gentry, J. W., Commuri, S., \& Jun, S. (2003). Review of literature on gender in the family. Academy of Marketing Science Review, 1, 1-18.

Gentry, J.W., \& Harrison, R. (2010). Is advertising a barrier to male movement toward gender change? Marketing Theory, 10 (1), 74-96.

Holbrook, M.B., \& Hirschman, E.C. (1982). The experiential aspects of consumption: consumer fantasies, feelings, and fun. Journal of Consumer Research, 9 (2), 132-140. 
Holbrook, M.B., \& Gardner, M.P. (1998). How motivation moderates the effects of emotions on the duration of consumption. Journal of Business Research, 42 (3), 241-252.

Hu, L.-T., \& Bentler, P.M. (1995). Evaluating model fit. in: Hoyle, R. H. (Ed.), Structural equation modeling: Concepts, issues and applications. (pp76-99). Sage, Thousand Oaks, CA.

Hutcheson, G., \& Sofroniou, N. (1999). The multivariate social scientist. London: Sage.

Hyllegard, K. (2005), Spanish consumers' perceptions of US apparel specialty retailers' products and services. Journal of Consumer Behaviour, 4 (5), 345-362.

Jepsen, A. L. (2007). Factors affecting consumer use of the internet for information search. Journal of Interactive Marketing, $21(3), 21-34$.

Kim, J., \& Forsythe, S. (2008). Adoption of virtual try-on technology for online apparel shopping. Journal of Interactive Marketing, 22 (2), 45-59.

Kline, R. B. (1998). Principles and Practice of Structural Equation Modeling. Guildford Press, New York.

Laforet, S (2008). Retail brand extension-Perceived fit, risks and Trust. Journal of Consumer Behaviour, 7 (3), $189-209$.

Maclaran, P., Hogg, M., Kozinets, R. \& Catterall, M. (2004). Gender, technology and computer-mediated communications in consumption-related online communities, in Ekstrom, K., \& Brembeck, H. (Eds.) Elusive Consumption, Oxford: Berg, 145171.

Marsh, H. W. (1985). The structure of masculinity/femininity: An application of confirmatory factor analysis to higher-order factor structures and factorial invariance. Multivariate Behavioral Research, 20 (4), 427-449.

Martin, B. A. S. (2003). The influence of gender on mood effects in advertising. Psychology and Marketing, 20 (3), $249-273$. McGinnis, L. P., Gentry, J. W., \& Gao, T. (2012). Antecedents to consumer perceptions of sacredness in extended service experiences: The case of golf. Journal of Service Research,

Mitchell, V., \& Walsh, G. (2004). Gender differences in German consumer decision-making styles. Journal of Consumer Behaviour, 3 (4), 331-346.

Neilson, L. A. (2010). Boycott Or Boycott? Understanding Political Consumerism. Journal of Consumer Behaviour, 9 (3), 214-227.

Noble, S. M., Griffith, D. A., \& Adjei M. T. (2006). Drivers of local merchant loyalty: Understanding the influence of gender and shopping motives. Journal of Retailing, 82 (3), 177-188.

Nunnally, J. C. (1978). Psychometric theory. Mcgraw-Hill, NY.

Otnes, C., \& McGrath, M. A. (2001). Perceptions and realities of male shopping behaviour. Journal of Retailing, 77 (1), 111 138.

Palan, K.M. (2001). Gender identity in consumer behaviour research: A literature review and research agenda. Academy of Marketing Science Review, 10, 1-28.

Pampel, F. C. (2000). Logistic regression: A primer. Sage Quantitative applications in the Social Sciences Series \#132. Sage Publications, Thousand Oaks, CA.

Rodgers, S., \& Harris, M. (2003). Gender and E-commerce: An exploratory study. Journal of Advertising Research, 43 (3), 322-329.

Roy, R., \& Ng, S. (2012). Regulatory focus and preference reversal between hedonic and utilitarian consumption. Journal of Consumer Behaviour, 11 (1), 81-88.

Sengupta, J., Dahl, D., \& Gorn, G.J. (2002). Misrepresentation in the consumer context. Journal of Consumer Psychology, 12 (2), 69-79.

Sheehan, K. B. (1999). An investigation of gender differences in on-line privacy concerns and resultant behaviors. Journal of Interactive Marketing, 13 (4), 24-38.

Smiler, A. P., \& Epstein, M. (2010). Measuring gender: Options and Issues. Handbook of Gender Research in Psychology, 2 , 133-157.

Smith, S.M., \& Whitlark, D. B. (2001). Men and women online: What makes them click? Marketing Research, 13 (2), $20-25$.

Thompson, C. (1996). Caring consumers: Gendered consumption meanings and the juggling lifestyle. Journal of Consumer Research, 22 (4), 388-407.

Van Slyke, C., Comunale, C. L., \& Belanger, F. (2002). Gender differences in perceptions of web-based shopping. Communications of the ACM. 45 (7), 82-86.

Wajcman, J. (1991). Feminism confronts technology. Pennsylvania: Penn State U. Press.

Wang, L. C., Baker, J., Wagner, J. A., \& Wakefield, K. (2007). Can a retail website be social? Journal of Marketing, 71 (3), $143-157$.

Wilkes, R. A., \& Laverie, D. A. (2007). Purchasing decisions in non-traditional households: The case of lesbian couples. Journal of Consumer Behaviour, 6 (1), 60-73.

Wood, M. (2005). Discretionary unplanned buying in consumer society. Journal of Consumer Behaviour, 4 (4), $268-28$. 